\title{
ARTICLES
}

\section{MODERATION IN FATWA AND IJTIHAD: JURISTIC AND HISTORICAL PERSPECTIVES}

\author{
Mohammad Hashim Kamali*
}

\begin{abstract}
This article jointly explores the various dimensions of fatwa and ijtihad, notwithstanding the former being our main theme. The two are explored together as there are many commonalities between them, the source evidence concerning the one often also relating to the other. The discussion begins with a comparative note on fatwa and ijtihad (independent reasoning), which is then followed by an expounding of the characteristic features of fatwa and its relevant procedures. Modern developments concerning fatwa issuance procedures are the subject of another section. These developments have led to a certain amount of bureaucratisation of fatwa, which has both its advantages and disadvantages. These are also explored and then followed by an overview of fatwa-related developments in Malaysia. The remainder of the article discusses the importance of observing moderation (wasatiyyah) in fatwa and ijtihad, which tends in many ways to characterise the typical Islamic advice and approach on these subjects. The article concludes with a set of actionable recommendations.
\end{abstract}

Keywords: Shariah, fiqh, mufti, modern developments, procedure, maqasid, legal maxims

\section{Fatwa and ljtihad: Commonalities and Differences}

Literally meaning a response, fatwa (pl. fatawa) is defined as a response given by a qualified scholar (i.e., a mufti) to a particular issue put to him by a person or a group of persons or an organisation. The mufti expounds the ruling of Shariah on the issue and conveys it to the questioner. Although recommended, it is not a requirement for a fatwa to explain the Shariah evidence on which it is founded. This is, however, a requirement of ijtihad. A fatwa issued by a competent scholar, who explains the evidential basis of his or her fatwa, and also includes an element of originality and research, may well be equivalent to ijtihad. ${ }^{1}$ Whereas a fatwa 
consists essentially of conveying (ikhbar) the ruling $/ \mathrm{hukm}$ of Shariah in response to a question, ijtihad consists of the extraction and formulation of such a ruling from the sources of Shariah, which means that ijtihad has stronger elements of originality and research. ${ }^{2}$ It is advisable for the mufti, however, to explain the rationale of his fatwa as well as its supportive Shariah evidence for purposes of educating and enlightening the questioner. Unlike testimony and adjudication, fatwa is not bound by any requirement of total impartiality. Thus, although a person is not allowed, for instance, to be a witness or judge in a case involving his relative, friend or foe, this is not a requirement in fatwa, since a fatwa consists mainly of ascertaining and communicating an existing rule of the Shariah. Also, a fatwa is not binding on anyone; a mufti may therefore issue a fatwa to anyone, including a friend or a relative. ${ }^{3}$

Fatwa and ijtihad both involve intellectual effort on the part of a qualified scholar to provide Shariah responses to real issues. The ruling that is arrived at, be it through fatwa or ijtihad, is often based on an understanding and interpretation of the Qur'an, Sunnah, general consensus (ijma) and other Shariah principles. The ruling so formulated consists of an opinion that does not bind the person or persons to whom it is addressed. The recipient of a fatwa is consequently free to refer the matter to another mufti and obtain a second, or even a third, fatwa on the same matter, none of which would be binding, and it is his choice whether or not to comply with any of them. Only in cases where the fatwa so issued consists of a clear injunction of Shariah and the two or three fatawa given are found to be concurrent would the fatwa then be binding on its recipient. This is a common feature of fatwa and ijtihad: neither is binding and both consist, at least partially, of an interpretation of opinion. Fatwa and ijtihad differ in this respect, however, from a judicial decision (qada), which binds the disputing parties and is enforceable on them. Qada is also not based on personal opinion, but on the $h u k m /$ ruling of Shariah. This is partly why a qadi is not supposed to issue a fatwa, except in respect of those parts of Shariah which are not justiciable, such as worship matters ( ibadat) and what may be considered recommendable (mandub) or reprehensible (makruh). It is reprehensible for a judge to issue fatawa concerning the rulings (ahkam) of Shariah, as this may have a bearing on his official duties as a judge - although some scholastic authorities have allowed it. ${ }^{4}$ This non-binding character of fatwa has, however, been changing in recent decades in many Muslim countries that have regulated the fatwa, made the office of mufti a part of the state bureaucracy, and even made the fatwa binding.

Another point of difference between fatwa and ijtihad is that fatwa may be attempted in matters which may have been regulated by decisive evidence or by mere indications in the Qur'an and Sunnah, and general consensus. Ijtihad 
does not proceed, however, over matters which are covered by decisive evidence in these sources. Whereas ijtihad often materialises when the learned scholar arrives at the ruling $(\mathrm{hukm})$ of an issue after due enquiry and research, a fatwa only comes into being when it is actually communicated to the questioner and its ruling is delivered to him. ${ }^{5}$

Ijtihad is, in principle, attempted by a qualified mujtahid, whereas a fatwa may be issued by such a person in addition to anyone who is knowledgeable in fiqh but does not possess the erudition of a mujtahid. A lesser qualified scholar may thus attempt a fatwa, especially when there is an urgent need for it and when a better qualified person cannot be found. A fatwa can, in other words, be issued by an imitator (muqallid) who is sufficiently knowledgeable to ascertain the ruling of Shariah and convey it to the questioner clearly and accurately. The fatwa must include the petitioner's question, a particular issue, and a definitive statement concerning its ruling by the mufti. ${ }^{6}$

Both fatwa and ijtihad partake in the collective obligation (fard kifa'i) of the Muslim community which, while it must not be neglected altogether, can be fulfilled when it is performed by only some members of the community, men and women alike. Issuing a fatwa without the required knowledge is prohibited (haram), for it may entail attribution of falsehood to the Lawgiver and may well misguide the people. ${ }^{7}$

The key Hanbali scholar, Ibn Qayyim al-Jawziyyah (d.1350CE), has warned against ascribing finality to the fatwa and ijtihad of anyone, including the mujtahidun of the past. To do otherwise would be to ignore the basic rule that fatwa and ijtihad are changeable with the change of times. To quote Ibn Qayyim:

This is a great aberration from the Shariah which is due to ignorance and causes unwarranted rigidity and hardship to the people... To facilitate benefit to the people in this world and the next is of the essence of Shariah. Anything which violates the people's benefit (maslahah) and leads them to corruption (mafsadah) has nothing to do with the Shariah, even if it is made out to be a part of it. ${ }^{8}$

'Abd al Rahman Taj, a prominent Professor of al-Azhar, has spoken on modern legislation in conjunction with fatwa and ijtihad, advising his Muslim readers to resist any temptation towards facile denunciation of modern legislation if it is issued in pursuit of the public interest: "It is incorrect to say that laws and policies that are initiated for the realisation of public interest are opposed to the Shariah merely because of some apparent discrepancy (mukhalafah zahirah) to one or the other proofs (adillah) of Shariah." Taj went on to say that before passing such a judgment, one must try to understand the purpose and spirit of the 
relevant evidence and "try to distinguish between those of the Shariah rules that contemplated a particular situation (ma warada 'ala sabab khass), and those that constitute general laws (tashri' 'amm). Only the latter are binding and must be observed." 9

Fatwa and ijtihad are both inherently dynamic. They are the principal vehicles for keeping the Shariah abreast with the realities of social change. They are also indispensable to the growth and development of Shariah, and cannot therefore admit of false limitations, such as the commonly recurrent misconception referred to as the "closure of the gate of ijtihad - sadd bab al-ijtihad." Even if this were accepted as a historical fact, which is not the case, it was conceptually erroneous and departed from the original impulse and teachings of Islam. ${ }^{10}$

\section{Fatwa: History and Procedures}

Historically, fatwa began as a private activity independent of state intervention and control. The 'ulama' who acted as muftis often responded to people's questions over issues and gave fatawa as a service to the community; they themselves set their professional standards usually without government intervention. They provided advice over questions of Islamic law and religion that people posed to them and solicited their assistance in court cases or for personal guidance. ${ }^{11}$

Fatwa is not permissible if it goes against the clear text or general consensus (ijma'). Nor should a fatwa be based on mere speculation and conjecture without a Shariah basis. Should there be conflicting views and interpretations in the sources, the mufti should not simply select an undigested position but try to verify and attempt, if possible, preference (al-tarjih) in order to establish a preferred position. ${ }^{12}$

A fatwa must be closely informed by the nature of the issue or incident it is addressing, and also verify correct application of the relevant rules. This is because real life situations and issues are hardly identical and may well involve new and unprecedented elements that require careful consideration. To give an example, person A asks a mufti whether he has to support his father. The obvious answer to this, found in all Shariah sources, is the general obligation of an affluent son to support his indigent father. But before issuing a fatwa in this case, it has to also be ascertained whether or not the son is indebted, and so whether his level of affluence is enough to support his wife and children. It might also be asked whether anyone among his immediate dependants happens to be ill and in need of special care and so forth. Only when all this is determined can a fatwa be issued. ${ }^{13}$

Scriptural authority for fatwa is found in several verses in the Qur'an, including al-Nisa' 4: 127 \& 176, where God Most High gives direction to the Prophet by 
way of fatwa. In the former verse, it is provided: "They ask you for instruction (yastaftunaka) concerning the women. Say God does instruct you about them..." The latter verse similarly provides concerning a question of inheritance, known as kalalah: "They ask you for a legal decision. Say: God directs you (yuftikum) about persons who leave no descendants or ascendants..."14 It is further added that the Prophet too acted as mufti to his followers in the sense of explaining the guidelines of the Qur'an to them. A mufti thus becomes successor to the Prophet in the sense of explaining God's ordinances and their application to the people in the context of the issues they encounter. ${ }^{15}$

In the event that a petitioner asks for evidence, and the evidence is a verse from the Qur'an or hadith and can be understood with a simple explanation, the mufti is required to comply. Muftis who adhere to a particular school of law, and who are not qualified to derive rulings directly from the textual sources, would be likely to cite an earlier reference work from within the school. Over the centuries, however, several reform movements arose in different parts of the Muslim world that sought to reduce the influence of imitation (taqlid) of prior works. ${ }^{16}$ This position has become even more popular in contemporary times, due mainly to the accelerated pace of socio-economic change and the fact that the nature of issues faced may well relate to new and unprecedented developments in science and civilisation.

When a mufti gives an erroneous fatwa, he falls into sin if he does so without having the necessary knowledge and qualification, or else that he is qualified but neglects to investigate and look into the issue carefully. He is not committing a sin, however, if he is qualified and applies himself well but still makes an honest error of judgment. He may revoke his own fatwa if his error becomes known to him, for it is preferable to stop falsehood at an early opportunity then allow it to perpetuate and cause greater harm. The second caliph 'Umar ibn alKhattab's advice to his fellow Companion and judge, Abu Musa al-Ash'ari, is often quoted in support of this position. The substance of that advice applies equally to adjudication and fatwa, ${ }^{17}$ just as it also provides support for the legal maxim that "Fatawa are changeable with the change of times." 18 This may be especially justified when the original fatwa was based on custom ('urf) or public interest (maslahah) at the time of its issuance. When there is a subsequent change in the underlying evidence of a fatwa, be it a custom or maslahah, then the fatwa based on it would also be liable to change. Further confirmation for this comes from the precedent of Imam Shafi'i, who developed his juristic thoughts in two separate phases. He changed many of the fatawa he had issued in Baghdad after his arrival in Egypt, because of the differences of culture and custom of Egyptian society that had bearings on his earlier fatawa.$^{19}$ This is why he is known to have established two madhhabs, an Old madhhab (al-qadim) and a New one (al-jadid). 
Subsequent changes in a fatwa are most likely to involve preference for that which better secures the higher purposes (maqasid) of Shariah. This also underlines a distinctive feature of the difference between the Shariah and fiqh. The former sets the higher goals and purposes, whereas fiqh devises ways and means to secure them. Fatwa and ijtihad are the means by which fiqh secures the higher purposes of Shariah. The means so applied may be accurate and authoritative, or else liable to speculation and error so that the weakness in them become apparent over time. The changeability of fatwa and ijtihad and their openness to subsequent rectification and amendment thus equips the Shariah with the tools to accommodate the changing conditions of society. ${ }^{20}$

Ibn Qayyim al-Jawziyyah relates the above to the principle that, if suppressing an evil leads to another evil greater and more objectionable to God and His Messenger, then it should not be suppressed. A fatwa, Ibn Qayyim alJawziyyah argues, is not only liable to change with time and considerations of public interest, but also by reference to the peculiarities of the issue with which a mufti may be faced - what is referred to in Arabic as munasabah (more appropriate) or mula'amah (harmonious). In such circumstances, something that one normally denounces and rejects may be left unchanged if suppressing it is likely to give rise to a greater harm/evil. Then in course of time, when conditions change, the next fatwa is likely to make the change that was earlier not feasible or appropriate to make. Examples that Ibn Qayyim has given in this connection include suspension of the prescribed penalties (hudud) during the year of the drought in the time of 'Umar al-Khattab, and allowing a menstruating woman to continue circumambulation of the Ka'bah during the hajj if she has travelled a long distance for the purpose. There is also the fatwa that allows testimony of one witness plus a solemn oath (the standard being two witnesses) during the time of 'Umar ibn 'Abd al-'Aziz ( d.101/721). All these exceptions were made for reasons of providing an appropriate response to a new situation and alleviating hardship, which is a higher purpose (maqsad) of the Shariah. ${ }^{21}$

To illustrate further the relevance of context and surrounding circumstances to fatwa, I refer to Ibn Taymiyyah (d. $1328 \mathrm{CE}$ ), who was asked for a fatwa concerning an unjust ruler who oppressed people and misappropriated public assets for his own gain. Ibn Taymiyyah was asked whether it was permissible to depose this ruler, even though he kept giving assurances that he would try and make improvements in the management of public affairs and despite the fact that there was a distinct possibility that deposing him would lead to chaos and revolt. Ibn Taymiyyah's response was that, if the ruler made an effort to establish justice and eliminate oppression, and if deposing him was likely to lead to unrest and chaos, he should be allowed to remain. Under the circumstances, this was deemed the lesser of two evils. ${ }^{22}$ 
On a similar note, Muhammad Rashid Rida (d. 1935) was asked for a fatwa by Nur al-Din, the then Mufti of Panjab (then in India). Rida was asked whether it was permissible for a Muslim to work under the British and act on British laws containing 'rulings other than God's revealed law - lam yahkum bi-ma anzal Allah.' Rida gave a detailed fatwa that ran into several pages, beginning with a review of the three relevant verses in the Qur'an, one of which declares those who rule according to anything other than God's revealed laws as 'infidels kafirun' (al-Ma'idah, 5:47). The other two verses make similar pronouncements, decreeing such rulers as 'oppressors-zalimun' (5:48) and 'transgressors - fasiqun' (5:50). Rida then quotes the renowned tenth-century CE Qur'an commentator, Ibn Jarir al-Tabari, to the effect that these verses were revealed concerning nonMuslims, mainly the Jews and Christians. According to another interpretation, the expression 'kafirun - infidels' in the said verse carries its literal meaning, in the sense of concealers of truth, its use thereby signifying a manner of emphasis and exaggeration, not kufr as disbelief per se. Rida concluded that employment for an Indian Muslim under the British may be tolerated as the lesser of two evils (akhaff al-drararayn) if no option existed for Muslim rulers and judges to act independently of the colonial power. Muslim judges and employees would thus be acting under the rules of necessity. ${ }^{23}$

The rules of conflict and preference (al-ta'arud wa'l-tarjih) as they relate to fatwa have been expounded in several legal maxims. The basic premise on which these rules proceed is that benefits and harm are mostly relative and contingent (nisbi, idafi) concepts, and that pure benefits and pure harms are rare. The prominent Shafi'i jurist, 'Izz al-Din 'Abd al-Salam al-Sulami (d. 1262/660), who was given the appellation Sultan al- 'ulama', underlined this by saying that real life situations tend to be mixed. In his estimation, when there is a conflict between two benefits (maslahatayn) and both cannot be obtained, or when a similar conflict exists between two harms and both of them cannot be avoided, or when a conflict is encountered between securing a benefit and preventing a harm, priority is to be attached to that which is greater and graver, even if it means loss of a minor benefit or toleration of a lesser harm. ${ }^{24}$ Al-Sulami continued: in the event of a combination of benefit and harm, if obtaining the former and preventing the latter is possible, this is should be done, as per the guidelines of the Qur'an. ${ }^{25}$ If this is not possible, however, and if the harm is greater than the benefit, preventing the harm is given priority and the loss of the benefit is tolerated. But, if the benefit in question is greater than the harm one is trying to avoid, the benefit should be secured and the harm tolerated. ${ }^{26}$ It is further added that the public interest takes priority over the private interest, and that the public interest is elevated to the rank of necessity and given priority over that which is a private necessity. This also means that the normal rules of law may be suspended 
by virtue of that necessity - as per a legal maxim of fiqh, which proclaims that "necessities make the unlawful lawful - al-darurat tabih al-mahzurat."

Among the etiquettes of fatwa (adab al-fatwa) that the figh blueprint underlines, one is that the mufti consider the condition of the questioner (mustafti) and make the fatwa understandable to him - if he happens to be slow of understanding, the use of vague and perplexing expressions should be avoided. The fatwa should, in other words, be succinct, address the question and avoid unnecessary expatiation, unless additional details are deemed necessary due to the gravity of the issue or in order to avoid misunderstanding. It was reported by the Companion 'Abd Allah ibn 'Umar, and confirmed by the Imams Malik and Ahmad ibn Hanbal, that the mufti should only attempt a fatwa in its proper context, avoid expatiation, and, if unsure of his response, refer the matter to a more knowledgeable authority. ${ }^{28}$ Although the normative position for the mufti is not to refuse to give a fatwa, he can do so if the subject happens to be too complex for the questioner or when the mufti fears that greater misunderstanding is likely to arise.

Also concerning the etiquette of fatwa, it is to be noted that the mufti should not be too eager in the issuance of fatwa. It is reported, for instance, that on about fifty separate occasions, Imam Malik replied to questions posed to him by saying "La adri - I do not know," whenever he was unsure of the answer. Similar responses have been recorded from Imam Ahmad ibn Hanbal and other prominent scholars.

Fatwa issuance is nowadays entrusted mainly to learned fiqh or Shariah academies and councils, although individual scholars also issue fatawa in their private capacities and in response to questions they have been asked, just as they also compile and publish their own collections of fatawa, often in large volumes. What we are seeing is thus a mixed pattern of the old and the new: collective and individual fatawa issued by muftis and scholars in their official and non-official capacities.

\section{Bureaucratisation of Fatwa}

The prominent Hanafi jurist, Ibn 'Abidin of Yemen (d. 1258/1842), wrote that a head of state should appoint muftis to the remotest regions of his dominion when there is a need for it and when qualified people are not found to perform the task voluntarily. Qualified muftis so appointed may also be paid from the public treasury for their services. The head of state should monitor the performance of these muftis and not hesitate to remove anyone who proves incompetent or who reverts all too readily to legal stratagems and tricks (hiyal, pl. of hilah) (i.e. who circumvent or suspend the normal rules of Shariah). ${ }^{29}$

More recently, various organisational patterns have emerged and fatwa activity 
has been regulated by statutory legislation. Although the elaborate bureaucracy associated with the office of the Ottoman Shaykh al-Islam, the chief mufti of the Empire, was discontinued when that office was abolished in 1924, similar institutions have since been established elsewhere. In Egypt, for example, the office of the Grand Mufti was established in late nineteenth century - although state muftis were not appointed until the mid-twentieth century. Saudi Arabia appointed a state mufti in 1953, Lebanon and Malaysia in 1955, Yemen and Indonesia in 1962 and 1975 respectively. In some institutional contexts, fatwa is now more closely associated with religious propagation and guidance $(d a$ 'wah and irshad) than with legal issues, as the legal affairs of states are often handled by other departments of government and legal professions. ${ }^{30}$

This bureaucratisation means that the state has acquired control of fatwamaking activity, with the obvious result that certain restrictions, as well as procedural requirements, have been imposed on the freedom of muftis and religious scholars in the issuance of fatwa. A positive aspect of this development has been the development of regulations that offer guidelines on the contemporary relevance of fatwa-making. These developments have also helped restrain those arbitrary fatawa that emanate from questionable sources and often play on people's religious sentiments. Yet the fact that a basically voluntary and investigative concept has been bureaucratised and placed under the control of the ruling authorities has necessarily restricted the free flow of thought and expression on topical issues of concern to Muslim individuals and societies. The muftis also seem to have been further distanced from the communities they serve; the open access that people earlier enjoyed to their muftis has been inevitably narrowed down. ${ }^{31}$

\section{Fatwa in Malaysia}

Considerations of space do not permit an adequate treatment of this subject here; the following few paragraphs merely constitute a brief note. ${ }^{32}$ In Malaysia, Islam is generally a state matter falling under the authority of the Sultans, each of whom is the head of religion in his own state. The King (Yang di-Pertuan Agong), on the other hand, is the head of religion in his own state, the Federal Territories, and all the states without a Sultan. The manner in which fatawa are issued and regulated in the various states of Malaysia differs from one state to another. The federal constitution of Malaysia, under the State List (Schedule 9), gives exclusive jurisdiction to the states to administer Islamic law, authorising them to establish their own Fatwa Committees. ${ }^{33}$ Fatwa issuance functions in the various states of Malaysia are regulated, in turn, under the state Enactments (usually known as Administration of Islamic Law Enactments), which entrust the relevant authority 
to the Sultan and the state Mufti, the latter of whom is also expected to work in close cooperation with the State Islamic Religious Council (Majlis Agama Islam) - although he remains, in principle, independent of the latter. A fatwa duly approved by the state Fatwa Committee and the Mufti, while also being assented to by the Sultan, only needs to be gazetted in order to acquire binding force in its relevant state. A Mufti's opinion alone, however, is not binding on anyone. Usually all Muslim family and personal law, coupled with laws relating to religious offences, are regulated by the respective state enactments.

For the Federal Territories of Kuala Lumpur, Putrajaya and Labuan, laws relating to Islam are passed by Parliament. In this context, the relevant Act of Parliament is the Administration of Islamic Law (Federal Territories) Act 1993. Section (37) of this Act provides that there shall be a committee known as the Islamic Legal Consultative Committee (henceforth the Fatwa Committee) that consists of a Mufti (Chairman), Deputy Mufti, two members of the Islamic Religious Council (Majlis Agama Islam), a minimum of two members to be appointed by the Majlis, and two others that are nominated by the Majlis. The Act further provides that the Mufti may make and gazette a fatwa or other ruling on any unsettled or controversial issue relating to Islamic law. Before a fatwa is made, however, the Mufti must first call a meeting of the Fatwa Committee to discuss the proposed fatwa. The Act also provides that before a fatwa is made, the Mufti may cause studies or other research to be conducted and a working paper prepared.

Another Act of Parliament, the Syariah Criminal Offences (Federal Territories) Act 1997, took a step further and made any fatwa duly issued and gazetted by the state authorities binding, even declaring it an offence for "any person who gives, propagates, or disseminates an opinion contrary to any fatwa in force." Anyone who does so will be committing an offence that carries a fine of up to RM3,000 or imprisonment for up to two years, or both. ${ }^{34}$

Although there is no Grand Mufti or central fatwa issuance body in Malaysia, there is the body commonly known as the National Fatwa Council (NFC) ${ }^{35}$ This is not an independent body, but the discussion forum (muzakarah) of the National Council for Islamic Affairs (NCIA - Majlis Kebangsaan Bagi Hal Ehwal Islam Malaysia). The NFC was established in the capital, Kuala Lumpur, in 1970 as part of NCIA and operates under the authority of the Conference of Rulers. The NFC consists of fourteen state Muftis representing all the individual states of Malaysia, as well as five other Muslim scholars appointed by the Council of Rulers and a member who is a Muslim from the legal or judicial profession. ${ }^{36}$ The Director General of the Islamic Development Department (JAKIM) also serves as a member, and JAKIM acts as the Secretariat of the NFC. ${ }^{37}$ The main functions of the NFC are to consider, decide and issue fatwa on any matter of 
concern to Islam that has been referred to it by the Conference of Rulers. The NFC responds to issues of national interest as and when the occasion arises. When such an issue arises, it recommends that a proposed fatwa be made and, when the Conference of Rulers agrees with the recommendation, action is duly taken to issue the said fatwa. All fatawa issued by the NFC are in the nature of an opinion and can only become binding when they are adopted by a state fatwa committee and duly gazetted. That is probably why all its ordinary meetings are named as muzakarah.

Over the years, the Malaysian public has seen fatawa issued by all the various fatwa committees on issues such as beauty pageants, e-cigarettes, vaping, yoga, Shishah smoking and other issues of concern to society, youth and women. The fatwa committees hardly issue fatawa on financial matters, however, as this sphere has become the exclusive concern of the Shariah Advisory Council at Bank Negara Malaysia, and its counterpart at the Securities Commission. Major banks and finance houses also have their own Shariah committees that examine and approve their Shariah-related transactions. A leadership role is thus in the making for the two national-level Shariah advisory Councils whose fatawa are strongly persuasive, even binding, on others, including in relevant disputed matters brought before the courts of justice.

Many international fatwa-issuance forums have also emerged in recent decades, both in the Middle East and Asia. These largely work in tandem with the rapid development of Islamic banking and finance. Some of these forums therefore specialise in certain aspects of Islamic banking and finance, such as accounting standardisation matters, liquidity management and other aspects of financial services. They are also active in the issuance and publication of Shariah standards, or Shariah perimeters and guidelines on IBF, which are adhered to, in turn, by Islamic banks and financial institutions worldwide.

To give an example, the basic prohibition against riba and banking interest has become an engaging theme for many of these learned bodies, with a large number of resolutions having accumulated over time in response to questions of, for instance, whether Islamic banks can impose penalties on late repayment of financing facilities and, if so, to what extent. Moreover, banks are normally allowed to charge fees for actual services they provide (e.g. letters of credit, letters of guarantee, credit cards, and other financial facilities and services) and a markup on sales in certain contracts (such as the cost plus profit sale, murabahah). In each case, however, questions have arisen over the methods of calculation of actual costs, the sum or percentages of service charges and mark up margins, and the like. These have sometimes giving rise to complex issues, and differential fatawa have been issued as a result. 


\section{Moderation (wasatiyyah) in Fatwa}

As the considered opinion of a scholar/s addressing a certain issue or question, it is possible for a fatwa to allow choice between a lenient (rukhsah) and a severe ('azimah) position about the permissibility of a certain matter. Alternatively, it may also resort to a legal stratagem (hilah) to circumvent a strict application of law. This last would be contrary to the religious requirements of moral uprightness (i.e. taqwa) but would be an available option under the fatwa. ${ }^{38}$ For fatwa and ijtihad to remain credible and reflect a balanced understanding of the Shariah, however, it is essential that they observe the principal Qur'anic message on the middle path of moderation, or wasatiyyah, while also remaining free of laxity, neglect, exaggeration and unnecessary strictures.

Wasatiyyah is characteristically comprehensive and emphasises the central meaning and message of any concept or phenomenon to which it is applied, in a manner that takes into account all (or most) of that concept or phenomenon's peripheries. Being a divinely-designated attribute of Islam and the Muslim community (cf. Q al-Baqarah, 2:143), wasatiyyah has helped to keep Islam centred on its own essentials, preventing parochial and rigid tendencies from dominating the religion. It has helped advocate a balanced vision of Islam that is inclusive of the interests of both the individual and society, while also keeping in sight its spiritual, rational, and scientific dimensions. Wasatiyyah is naturally about striking a middle and conciliatory position between traditional and modernist understandings of Islam, not only for the present generation, but also for those who follow. ${ }^{39}$ The mufti and mujtahid are thus advised not to indulge in expatiation in tasawwuf, nor in the totally materialist ways of worldly life. The Prophet (pbuh) has warned the believers that: "People who came before you were met with destruction because of their extremism (al-ghuluww) in the religion."

With reference to legal and fiqhi matters that are open to interpretation through fatwa and ijtihad, schools and scholars have often recorded differences of opinion. Credibility, however, is usually attached to the majority (jumhur) position. The renowned Maliki jurist, Ibrahim al-Shatibi of Andalus (d. 790/1388), who is highly regarded for his pioneering work on the maqasid of Shariah, therefore considered it a mark of distinction for a mufti and mujtahid to consider those opinions which the majority supported in the issuance of their own fatwa, verdict and ijtihad. In this connection, he quotes the reference in the first surah of the Qur'an, namely al-Fatihah, to 'the straight path' (al-sirat al-mustaqim), which he says is the chosen path of moderation. Hence moderation is a purpose (maqsad) of the Lawgiver and it is expected that all Muslims, especially the learned among them, hold to it and guard against indulgence in excessiveness (such as rejecting 
the majority) or reductionism. "When the mufti leaves the path of moderation, he also neglects the purpose/maqsad of the Lawgiver, and is likely to invite criticism from the leading 'ulama'."'41

The higher purposes of Shariah have been classified into various categories, depending on the purpose of the classification and viewpoint of the researcher. In all cases, however, a certain order of priority has been ascertained between the categories that needs to be carefully observed in the formulation of fatwa and ijtihad. From the viewpoint of their importance, the maqasid have been divided into three categories: essential purposes (daruriyyat), complementary purposes (hajiyyat), and embellishments (tahsiniyyat). Only the first of these has been further subdivided, namely into the five headings: protection of life, preservation of religion, upholding the integrity of the human intellect, protecting the family, and protecting of lawfully-owned property. These must be safeguarded as a matter of priority, both by individuals and the community, as well as the muftis, 'ulama' and government authorities, all of whom are, in principle, under an obligation to observe and promote them.

Al-Qaradawi has written concerning a recurrent theme in the Qur'an and Sunnah, namely bringing ease to the people by removing hardship from them (taysir wa raf'al-haraj). In the event of a choice between an easier and a more difficult fatwa, al-Qaradawi advises that the mufti should try to opt, as far as possible, for the former in order to avoid inflicting hardship on the people but without, however, compromising on principles. He warns against opting for difficult solutions and scare-mongering in Islamic discourse, inquiry and research, as they only help to turn people away from the path of God. ${ }^{42}$

With reference to the leading schools of law (madhahib), al-Shatibi observed that all of them are merely different paths to the discovery of truth and gaining of God's pleasure. But, the most preferable amongst them for the mujtahid, or even the imitator (muqallid) who simply follows, is the one that comes closest to the purpose (maqsad) of the Lawgiver, which is the median position of wasatiyyah. This is because the Lawgiver has expressly commended moderation, which is reflected, in turn, by the Sunnah of the Prophet and the practice of his leading Companions. Al-Shatibi concludes with a remarkable statement, saying that the median position is "the greatest [part] of Shariah and the mother of the Book - fa'l-wasat huwa mu'zam al-shari'ah wa umm al-kitab." ${ }^{\prime 43}$ This position is similarly reflected by the Syrian scholar and author of a book on wasatiyyah, 'Abd al-Latif al-Farfur (d. 1435/2014) who wrote:

The middle way of moderation is the norm and principle of Islam. Whenever a ruling of Shariah is found to depart from it, it is most likely due to exceptional conditions, necessity or need based on identifiable 
causes. The normative position of wasatiyyah must be restored to when exceptional situations come to an end. Rationality and Shariah stand together in their rejection of both reductionism and excess, exaggeration and neglect. ${ }^{44}$

Moderation is identified through rationality (' $a q l$ ) and human judgment, which are both key to knowledge and understanding. Sound intellect is naturally inclined towards moderation, especially when it is enlightened and well-informed. This also means paying adequate attention to existing bodies of specialised knowledge, including that of the modern disciplines, as well as the differences of opinion amongst the learned. This is a responsibility one can hardly afford to neglect, for it is a reliable way of ascertaining and verifying moderate positions. Rational judgement will not entertain rectifying an extremist position with an extreme remedy, nor an erroneous one through error. Neither will it abandon rationality in favour of emotional indulgence, personal interest or bias. ${ }^{45}$

General consensus (ijma') of the learned members of a community, or of the community as a whole, is another important indicator of balanced opinion and judgment in Islam. Notwithstanding a degree of technicality in the detailed formulations of ijma', its inherent strength as a source of law, judgment and moderation can hardly be overestimated. Consensus is normally preceded by consultation (shura), itself a Qur'anic principle of special significance for community affairs. Shura must be solicited from members of the community able to provide a considered opinion on contested issues of public concern. Whenever consultation leads to consensus - and here we do not mean the somewhat technical usuli concept of ijma', but consensus generally - it becomes an important indicator of balanced and moderate opinion in the determination of issues. Consultation and consensus can take a variety of forms, from relatively informal village, district and municipal councils, to the more organised elected assemblies of parliaments and other government bodies, all of which are acceptable, provided they are genuinely representative and their participants enjoy the freedom to voice their views.

Well-moderated judicial positions have been identified by the Shariah, and more widely by both general custom ('urf) and what sound-minded people have considered to be moderate. General custom is a recognised source of judgment in Shariah, applicable to matters not regulated by the clear text. It is also an important indicator by which wasatiyyah can be ascertained on issues of public concern, including financial and customary matters. Custom and rationality may even take preference over an existing fiqhi position and precedent. An example of a (somewhat exceptional) circumstance where this happened is the construction of the Umayyad Mosque of Damascus under caliph Walid ibn Abd 
al-Malik (d. 95/715). This impressive edifice, which was exceptionally ornate and expensive, marked a departure from the simplicity of structure and style recommended for mosques by fiqh. It is reported that 'Abd al-Malik's successor, the pious caliph 'Umar ibn 'Abd al-Aziz (d. 101/721 CE), intended to destroy the mosque for this reason, but changed his mind when he was informed that Damascus was being frequented by courtiers of the Roman Emperor, making it a question of prestige for the Muslims to have similarly impressive buildings as those of the Romans. After this consultation, the Caliph acceded and abandoned what he thought was a moderate fiqhi position in favour of a certain amount of extravagance. $^{46}$

With reference to technical issues of a specialised nature pertaining to, for example, applied sciences, it is not always the moderate or average position that is wanting, but one that is correct only in light of the available body of knowledge. This can also perhaps be said with regards to legal and Shariah-related matters of a specialised nature, which may have to be determined in the light of relevant evidence. ${ }^{47}$

Moderation may also be recognised, according to al-Shatibi, by reference to the prevailing law [in our time also the national charter and constitution]; it may likewise be recognised through the benefits which are likely to accrue from a particular opinion or course of action. ${ }^{48}$

In the event of a conflict arising between benefits and harm (masalih wa mafasid), a jurist and mufti may be faced with uncertainties over balancing the two in the light of wasatiyyah. As mentioned above, he would need to observe the relevant guidelines of Shariah, while also considering the greater benefit that may be involved, even if securing it means tolerating a certain amount of harm. This may place the jurist/mufti in a situation where he has to abandon the side which is decidedly harmful, even if it involves losing out on a possible benefit. Upholding the average mean in this case, as in most other cases of reconciling conflicting interests, also necessitates a careful assessment of the status quo and the likely consequences of departing from it towards a compromise solution that helps to secure the greater benefit.

The forgoing is illustrated by the restrictions Islamic law imposes on the legal dispositions of an incompetent person (al-safih) through a retraining judicial order, or interdiction (al-hajr). Thus, it is ruled that in regards to contracts and transactions that are amenable to adjustment and repeal, such as sale, lease and hire, the safih is neither totally restricted nor totally free - an intermediate position is taken so that, when such a transaction is attempted by the safih, it is valid subject to the approval (even if obtained after the event) of his or her guardian (wali). A purely harmful transaction, such as giving a gift, is deemed invalid, but one which is deemed beneficial, such as receiving a gift or a share in 
inheritance, is held to be valid and effective without anyone's approval. This is how the schools and jurists of Shariah have tended to take a moderate approach in situations of conflicting interests, which in this case is to protect the personal liberty of the person under interdiction while also protecting their property against squandering and waste. ${ }^{49}$

Available precedent suggests that when pressing issues of conflicting public and private interests were encountered by the early pioneers of Islam, including the second caliph 'Umar al-Khattab, they attempted a moderate solution through a feasible interpretation of the Qur'an and hadith, or by recourse to consultation (shura) and independent reasoning (ijtihad)..$^{50}$

Amongst contemporary examples of wasatiyyah is the decision by Ugandan religious leaders to join hands with the HIV/AIDS campaign in the early 1990s, and the success that has been achieved as a result. The situation, according to Dr Magid Kagimu Salonga, Chairman of the Islamic Medical Association of Uganda (IMAU), was grim until Muslim religious leaders began educating themselves about the epidemic disease. They attended workshops on AIDS and made the campaign to defeat it an integral part of their mosque sermons. The project, which started with two districts in 1992, spread to ten of Uganda's 45 districts in five years. Since then, "IMAU has trained 6,800 volunteers through the involvement of 850 mosques." 1 IMAU also undertook a project to reach out to Muslim children - the so-called Madrasa AIDS Education and Prevention Project. Under this project, local imams taught school and madrasah children about AIDS.

Initially, condom use was not mentioned in the Ugandan approach to HIV/ AIDS campaign, but thanks to the above this is now possible, at least in the context of marriage. With the necessary knowledge and understanding, Uganda's "religious leaders, who are very influential in the community," proved to be instrumental in changing people's attitudes toward HIV/AIDS, especially in eliminating discrimination and prejudice. As a result, Uganda has become the only African country to report a decline in HIV infections in various population groups since the mid-1990s. ${ }^{52}$

The muftis of today need to engage with their communities through the exchange of views and dialogue, in order to ascertain the conditions of the various strata of society, especially the youth and women. This will need a diversified approach, in accordance with the particular issues and concerns of these groups in light of the prevailing conditions of society. ${ }^{53}$ In this connection, al-Qaradawi has, and perhaps on a broader note, pointed to a need for building bridges and strengthening cultural ties between the various countries and communities of the "contemporary larger Arab community in light of the broader civilisational objectives of Islam." 54 
According to al-Shatibi, negligence and excess are both transgressions which should be eliminated. This may require defining the issues first, clarifying the available guidelines on them, and then the proper manner of dealing with them. This may further require delineation of what is deemed essential as opposed to what may be optional and belong to the realm of enhancements (tahsiniyat). ${ }^{55}$

On an historical note, Muslim communities have known a wide spectrum of doctrines and movements, not all of which have survived to the present. The Zahiri school of Daud al-Zahiri (d. 885CE), for example, declined and became extinct, mainly due to its rigidity and literalism. So too did the school of the $\mathrm{Ahl}$ $a l-R a^{\prime} y$ (partisans of opinion), who took liberties and engrossed themselves in speculative reasoning and analogies to the extent of distancing themselves from authoritative Sunnah. The middle course in between these two is believed to be that of the dominant majority (jumhur). But even the majority have at times been unable to take a clear position on certain issues. Note, for instance, the diverging views apparent during the early decades of Islam, between the Kharijites (lit. outsiders), the Mu'tazilites (lit. secluders) and the Jabarites (lit. determinists) on such theological and philosophical issues as whether the Qur'an was the created or uncreated speech of God, on the exalted Self (dhat) and attributes (sifat) of God, free will and predestination, as well as political issues of concern to governance, leadership and so forth. No one, it seems, had the answers, let alone moderate ones - if one could employ the word in such situations. What was the middle course of wasatiyyah in regard to those issues? Some theological questions cannot be answered and thus remain indefinitely speculative and controversial.

Thanks to the moderating influences of consensus and public opinion, however, fresh perspectives were advanced and developed in course of time. Over many instances of extremism and excess, a middle course was often successfully identified. Extremist factions and advocates of excessive views were isolated and marginalised.

\section{Conclusion and Recommendations}

The foregoing analysis of the various aspects of fatwa and ijtihad sustains the following set of actionable recommendations.

1. Fatwa should generally be seen as an instrument of facilitation that brings ease and helps reconcile people's legitimate needs and convenience with the principles of religion and Shariah. Fatwa issuers should avoid, as far as possible, facile declarations of this and that as being haram without there being decisive Shariah evidence to support such.

2. The ages of science and globalisation have brought fatwa and fatwa issuance 
procedures under fresh scrutiny. They have also brought new factors into play that tend to make fatwa more inter-disciplinary than ever before.

3. Malaysia is not untypical of other Muslim countries in that it is experiencing a rapidly growing young population exposed to unprecedented levels of information and the tools by which that information can be obtained. Under these circumstances, it is advisable that new channels of communication be found to connect muftis and fatwa-issuance authorities with the youth (and also women) more effectively.

4. Fatwa has, to all intents and purposes, become a manifestation of official ijtihad, in that muftis are acting much like 'ulama', the traditional repositories and carriers of ijtihad. The lay 'ulama' should still, however, be allowed to influence, not only the muftis, but also parliamentary legislation on religious issues away from official control. Any new guidelines that are deemed necessary to regulate ijtihad should be approved by the 'ulama' themselves.

5. Fatwa issuance should not be privatised in the way that is becoming increasingly common in the Islamic banking and finance sectors. The money factor, and the fact that banks and money-houses are paymasters to their own Shariah committees in Malaysia (as elsewhere), calls for a revision in order to establish a balance of influences in the working modalities of Shariah committees and advisors.

6. Developments in Malaysia over the past decade relating to the leadership roles of the Shariah Advisory Council of the Central Bank of Malaysia, and that of its equivalent in the Securities Commission, are a move in the right direction. These developments are not only likely to help develop a measure of professional supervision of the various other Shariah committees, but will also help standardise the substantive and procedural aspects of fatwa issuance in the Islamic banking and finance sectors.

7. Fatwa has, to all intents and purposes, become a parallel instrument of lawmaking in Malaysia. This tendency is growing in other Muslim countries as well. Within the constitutional structure of federalism in Malaysia, state authorities assert their own roles in religious matters, stating that they make their own laws. This tends to work against the idea of uniformity and standardisation, which has, on the whole, remained at a low level in Shariah and religious matters in Malaysia - and notwithstanding the decades of committee work to help reduce disparities in the Shariah judiciary.

8. The bureaucratisation of fatwa has advantages and disadvantages, as already explained. Further advances in this direction should, however, be minimised and discouraged; additional bureaucratisation will inevitably invite criticism from both the lay 'ulama' and muftis about impinging on academic and professional freedom. 
9. Fatwa should be seen as an important instrument of wasatiyyah (moderation), which also happens to be the official policy programme of the incumbent government of Malaysia, under Prime Minister Najib Razak. Emphasising this link will require effective communication and understanding between all concerned parties. It is questionable, however, whether this level of coordination over the role of fatwa in wasatiyyah exists in Malaysia.

10. The moderating role of fatwa should be one of the principal functions of both the National Fatwa Committee in Malaysia and its counterparts in other Muslim countries. Fatawa issued by the state authorities should also receive the approval of the NFC before being officially gazetted.

\section{Notes}

* Mohammad Hashim Kamali, Founding CEO of IAIS Malaysia, graduated from Kabul University, and took his PhD in Islamic and Middle Eastern Law at the University of London in 1969. Professor Dr M. H. Kamali served as Professor of Islamic Law and Jurisprudence at the International Islamic University Malaysia (IIUM, 1985-2007), then Dean of the International Institute of Islamic Thought and Civilization (ISTAC). He also held Visiting Professorships at McGill University's Institute of Islamic Studies; Capital University, Ohio; and the Wissenschaftskolleg, Berlin. A member of the Constitution Review Commission of Afghanistan (2003), he has provided expert legal consultation to the new constitutions of Iraq, the Maldives and Somalia. Eminent authority on Islamic legal studies, he has published over 170 academic articles and 35 texts, including standard textbooks at universities worldwide. He can be contacted at ceo@iais. org.my.

1. Cf., Wizarat al-Awqaf wa'l-Shu'un al-Islamiyyah, al-Mawsu'ah al-Fiqhiyyah (Kuwait), "Fatwa," Vol. 32, p. 25.

2. Examples of brief questions put to a mufti may be when someone asks him: "Is it an obligation for me to support my parents?" or "Can I give a blind animal in sacrifice for 'Id al-Adha?" Whereas the fiqh books usually record questions of this nature, in our times, muftis and scholars of Shariah are often confronted with a wider mix of socio-religious, financial and political issues and questions, which means that no ready answers may be available and the mufti may be called upon to explore and research the source evidence more often than might have been the case in earlier times.

3. al-Mawsu'ah al-Fiqhiyyah (Kuwait), "Fatwa," Vol. 32, p. 31.

4. Ibn Qayyim al-Jawziyyah, I'lam al-Muwaqqi'in, Vol. 4, p. 220; al-Mawsu'ah al-Fiqhiyyah (Kuwait), "Fatwa," Vol. 32, pp. 31-32.

5. Cf., al-Mawsu'ah al-Fiqhiyyah (Kuwait), "Fatwa," Vol. 32, p. 22; Yusuf alQaradawi, al-Fatwa bayn al-Indibat wa'l-Tasayyib, p. 12.

6. al-Mawsu'ah, Vol. 32, p. 26.

7. Cf., al-Mawsu'ah al-Fiqhiyyah, Vol. 32, pp. 21-22. 
8. Muhammad b. Abu Bakr lbn Qayyim al-Jawziyah, I'läm al Muwaqqi in 'an Rabb al Älamin, Cairo: al-Kulliyah al Azhariyah. 1388/1968, IV, p. 309.

9. Taj, al Siyasah, p. 21.

10. It is almost taken for a fact that ijtihad came to a close around the beginning of the fourth century A.H. There is, however, much evidence to the contrary and which suggests that ijtihad was never discontinued. See for example, Wael Hallaq, "Was the Gate of Ijtihad Closed," International Journal of Middle East Studies 16, 1984. p. 341.

11. Cf., Mohammad Hashim Kamali, "The Johor Fatwa on Mandatory HIV Testing," IIUM Law journal, Volume 9, No. 2 (2001), p. 111.

12. al-Mawsu'ah al-Fiqhiyyah (Kuwait), "Fatwa," Vol. 32, pp. 33-34.

13. Ibid., p. 26.

14. A reference to fatwa also occurs in sura Yusuf (12:43), while its explanatory function is mentioned in al-Nahl (16:44).

15. See for details al-Mawsu'ah al-Fiqhiyyah (Kuwait), "Fatwa," Vol. 32, 1-50, at p. 23.

16. Cf., Musa Furber, "The Elements of a Fatwa and other Contribution to Confidence in its Validity," Taba Analytic Brief No. 14, Tabah Foundation, Abu Dhabi, 2013, p. 2.

17. Ibn Qayyim al-Jawziyyah, I'lam al-Muwaqqi' in 'an Rabb al-'Alamin, Vol. 1, p. 86.

18. Ibn Qayyim al-Jawziyyah, I'lam al-Muwaqqi'in, Vol. 3, p. 38 - discusses this under the heading "Change of fatwa and its variation abreast with the change of times, places, conditions, and customs."

19. See, for a discussion, Sulayman Muhammad al Tamawi, al Sulatat al Thalath $f i$ Dasatir al 'Arabiyah wa fi'l fikr al Siyasi al Islami, Cairo: Dar al Fikr al 'Arabi, 1973, p. $305 \mathrm{ff}$.

20. Cf., Tariq al-Bishry, "al-Jama'ah al-Wataniyyah fi Daw' Maqasid al-Shari'ah," in ed. Mohamed Salim el-Awa, Taf'il Maqasid al-Shari'ah fi Majal al-Siyasi: Majmu'ah Buhuth, London: Mu'assasah al-Furqan li'l-Turath al-Islami, 2014/1435, p. 138.

21. Ibn Qayyim al-Jawziyyah, I'lam al-Muwaqqi'in, Vol. 3, p. 10 \& 14; al-Bishry, “al-Jama'ah al-Wataniyyah," p. 139.

22. Ibn Taymiyyah, Majmu' Fatawa Ibn Taymiyyah, Vol. 30, p. 356, also recounted in al-Ahmad al-Raysuni, "Tawalli al-Manasib al-Mukhtalata bi'l-Haram fi Daw' al-Nazar al-Maqasidi," in ed. Mohamed Salim el-Awa, Taf'il Maqasid alShari'ah, p. 281.

23. Muhammad Rashid Rida, Tafsir al-Manar, Vol. 6, 335 as cited by Ahmad alRaysuni, "Tawalli al-Mansib," in ed. El-Aw, Taf'il al-Maqasid, pp. 283-289.

24. 'Izz al-Din 'Abd al-Salam, Qawa'id al-Ahkam fi Masalih al-Anam, Vol. 1, p. 5.

25. The Qur'anic verse al-Sulami specifically quoted was: "So fear God to the extent of your ability," (al-Taghabun, 64:16).

26. Al-Sulami, Qawa'id, Vol.1, p. 110.

27. Ibid., Vol. 1, p. 188.

28. According to a hadith, albeit one thought to be a Mursal (disconnected), it is reported that the Prophet said: "The most prompting of you in fatwa is most prompting on (Hell) fire - ajra'ukum 'ala'l-futya ajra'ukum 'alan-naar.' 
Recorded by al-Darimi on the authority of 'Ubaydullah b. Abi Ja'far. See alMawsu'ah al-Fiqhiyyah (Kuwait), Vol. 32, p. 23.

29. Muhammad Amin ibn 'Abidin, Hashiya Radd al-Mukhtar 'ala Durr al-Mukhtar, Vol. 5, p. 93.

30. Cf., Muhammad Khalid Masud, Brinkley Messick and David S Powers, "Muftis, Fatawa, and Islamic Legal Interpretation," in Eds. Muhammad Khalid Masud, Brinkley Messick and David S Powers, Islamic Legal Interpretation: Muftis and Their Fatawa, Cambridge and London: Harvard University Press, 1996, p. 27.

31. See for details Kamali, "Johor Fatwa," p. 113.

32. A fuller treatment of the subject can be found in a very good Article by Mohamed Azam Mohamed Adil, "Standardisation of Fatwa in Malaysia: Issues, Concerns and Expectations," Islam and Civilisational Renewal," Vol. 6, no. 2 (April 2015), pp. 196-211.

33. In addition to Fatwa Committee, these bodies are called by various other names in the different states of Malaysia, including Lajnah Fatwa, Jamaah Ulamak, and Islamic Legal Consultative Committee (J. Perundingan Hukum Syarak).

34. Syariah Criminal Offences (Federal Territories) Act, 1997 (Art. 12); Syariah Criminal Offences (Selangor) Enactment 1995 (Section 13(1)); Syariah Criminal Offences Enactment of Johor (S.12) and its equivalent provisions in most other states of Malaysia. See for further information Rajen Devara, "Understanding Fatwa in the Malaysian Context," http//Aliran.com/archives/monthly/2005a/2h. html (retrieved 25 August 2016).

35. http://www.themalaymailonline.com/malaysia/article/deputy-minister-natinalfatwa-council-incorrect-term\#sthash.xQSAO9AV.dpuf

36. Mohamed Azam Mohamed Adil, "Standardisation of Fatwa in Malaysia: Issues, Concerns and Expectations," Islam and Civilisational Renewal, Vol. 6, no. 2 (April 2015), p. 198.

37. JAKIM has other functions, including enhancing coordination among the fatawa issued by both the various states' fatwa committees and the federal government in order to develop the process of collective ijtihad (ijtihad jama' $i$ ) in the country.

38. Cf., Muhammad Khalid Masud, "Fatwa," The Oxford Encyclopedia of the Modern Islamic World, ed. John L. Esposito, OUP, 1995, Vol. 2, p. 9.

39. Cf., Tha'ir al-Shimri, al-Wasatiyyah, Beirut: Dar al-Kutub al-'Ilmiyyah, 2005/1426, pp. 42-3.

40. Ahmad ibn Hanbal, al-Musnad li'l-Imam Ahmad ibn Muhammad ibn Hanbal, Vol. 2, Cairo: Dar al-Hadith 1995, p. 349, hadith no. 1732.

41. Al-Shatibi, al-Muwafaqat fi Usul al-Ahkam, annotated by M. Khidr al-Husayn, Cairo: al-Matba'ah al-Rahmaniyyah, 1341/1923, vol. 2: $163 \mathrm{ff}$.

42. Yusuf al-Qaradawi, "Minal-Ghuluwwwa'l-Inhilal ila'-Wasatiyyah wa'l-I'tidal," in Mu'assasah Aal al-Bayt al-Islami, Mustaqbal al-Islam fi Qarn al-Hijri alKhamis al-'Ashr, Jordan: Amman, 1425/2004, 312. See for details Mohammad Hashim Kamali, The Middle Path of Moderation in Islam: The Qur'anic Principle of Wasatiyyah, New York and London: OUP, 2015, p. $128 \mathrm{f}$.

43. Al-Shatibi, al-Muwafaqat, Vol. 4:258. For further discussion, see also al-Farfur, al-Wasatiyyah, 79 and 160.

44. Al-Farfur, al-Wasatiyyah, pp. 159-60.

45. Cf., al-Farfur, al-Wasatiyyah, p. 63. 
46. Ibid., p. 102.

47. Al-Shatibi, Al-Muwafaqat fi Usul al-Ahkam, Vol. 3:163.

48. Abu Ishaq Ibrahim al-Shatibi, Al-Muwafaqat fi Usul al-Shari'ah, $2^{\text {nd }}$ ed. Edited by 'Abd Allah Darraz, Beirut: Dar al-Ma'rifah, 1975, Vol. 2:167-8.

49. Cf., 'Abd al-Karim Zaydan, al-Wajiz fi Usul al-Fiqh. Beirut: Mu'assasah alRisalah, 1985/1405, 118. See also Tha'ir al-Shimri, al-Wasatiyyah, p. 56.

50. Many examples are recorded of fresh ijtihad by Caliph 'Umar. For instance, during his reign he oversaw the distribution amongst Muslim warriors of fertile land (sawad) in Iraq. This distribution constituted part of the war booty to which the Qur'an entitled warriors, but which the caliph amended by reconciling the relevant passages of the Qur'an with certain other verses, thus arriving at a different solution. The Caliph also moderated a ruling of the Qur'an on inheritance in the renowned case of al-Mushtarakah (also known as al-Himariyyah). This was a peculiar case which initially saw the half-brothers of the deceased take one-third of the estate, to the total exclusion of the full brothers. The latter complained to the Caliph and, after lengthy consultations with the Companions, he arrived at a compromise solution to allow the one-third to be shared equally by all the brothers. Cf., Tha'ir al-Shimri, al-Wasatiyyah, pp. 57-8.

51. Ivy Soon, "Islamic clergy confront AIDS issue," Sunday Star, December 2, 2001, p. 22.

52. Ibid., Uganda's successful experience inspired a delegation of seven Malaysian religious scholars to visit IMAU operations. They attended an 'International Muslim Leaders' Consultation group on HIV/AIDS, where they networked with religious leaders from other countries who were also involved in the AIDS education campaign.

53. For a fuller discussion of hiwar in the Qur'an and hadith see Al-Qaradawi, Thaqafatuna Bayn al-Infitah wa'l-Inghilaq, 49f.

54. Ibid., p. 158.

55. Ibid., 2:24. 